\title{
Environmental risk factors for childhood asthma in a Semi-urban area of Western Tamilnadu
}

\author{
Muraleetharan $\mathbf{G}^{1}$, Anuradha $\mathbf{G}^{2}$, Vanishree $S^{3}$, Sachithanantham $\mathrm{S}^{4}$ \\ ${ }^{1}$ Dr. Muraleetharan G, Associate Professor, ${ }^{2}$ Dr. Anuradha G, Assistant Professor; both authors are affiliated with \\ Department of Paediatrics, IRT Perundurai Medical College, Erode, ${ }^{3}$ Dr. Vanishree S, Associate Professor, Department \\ of Community Medicine, Sri Ramachandra Medical College, Chennai, ${ }^{4}$ Dr. Sachithanantham S, Librarian, IRT \\ Perundurai Medical College, Erode District, Perundurai, Tamil Nadu 638053, India.
}

Address for Correspondence: Dr. G. Muraleetharan, Email; drmuraleetharang@yahoo.co.in

\begin{abstract}
Introduction: Environmental determinants are integral part of etiology, severity and management of asthma. But the association between various indoor and outdoor triggers with pediatric asthma has been inconsistent, complex and variable across the globe. This study was aimed at identifying the environmental risk factors associated with childhood asthma in our region. Methods: This was a hospital-based cross-sectional study done at Perundurai Medical college hospital, Tamilnadu. After getting Institutional Ethical Committee approval, children in the age group of 2 to 15 years attending the pediatric outpatient department were enrolled in the study. Parents were interviewed with ISAAC questionnaire and history of exposure to various indoor and outdoor triggers was recorded in addition to the basic demographic details and anthropometric indices. Data was analyzed using Chi-square tests and logistic regression analysis. Results: Among 500 subjects, 298 (59.6\%) were asthmatics and 202 (40.4\%) were non-asthmatics. Age group of 6-10 years (OR 1.94, 95\% CI 1.20- 3.13), male gender (OR 2.26, 95\% CI 1.47-3.48), overweight/obesity (OR 3.70, 95\% CI 1.17-11.66), mould (OR 2.43, 95\% CI 1.37- 4.32), seasonal variation (OR 2.39, 95\% CI 1.51-3.79) and outdoor air pollution (OR 6.17, 95\% CI 4.00- 9.53) were independently associated with childhood asthma. Passive smoking, type of cooking fuel, absence of smoke outlet, exposure to animals and proximity of house to arterial road were not significantly associated with asthma. Conclusion: Environmental triggers play a significant role in pediatric asthma. Appropriate interventions to mitigate these modifiable risk factors would decrease the burden of the disease substantially.
\end{abstract}

Keywords: Asthma, Children, Risk factors, Environment, Air pollution, Indoor

\section{Introduction}

Asthma is the chronic inflammatory disease of the airways, which demonstrates significant heterogeneity in etiology, clinical manifestations and natural history $[1,2]$. Globally, 334 million people suffer from asthma and the burden of asthma is greatest for children aged 10-14 and the elderly aged 75-79 [3]. The prevalence of asthma and allergies in general has substantially increased over the last two decades, particularly among children [4] and there is considerable variability in prevalence across countries [5-7]. Studies of migrant populations have demonstrated the influence of the duration of stay in the new living environment and significant changes in the risk of asthma after migration [8]. These observations suggest that environmental

Manuscript received: $17^{\text {th }}$ February 2017

Reviewed: $25^{\text {th }}$ February 2017

Author Corrected: $4^{\text {th }}$ March 2017

Accepted for Publication: $11^{\text {th }}$ March 2017 factors may be largely responsible for childhood asthma in combination with the genetic and atopic propensity of the child. The indoor triggers include aeroallergens associated with cats, dogs, birds, dust mites, rodents, cockroaches and moulds, environmental tobacco smoke (ETS) and use of biomass fuel (BMF) for cooking and heating [9]. Air pollutants comprising particulate matter (PM), toxic gases, traffic-related air pollution (TRAP) and pollens constitute the predominant outdoor triggers.

Except for moulds, researches on the role of other environmental triggers in inducing new onset pediatric asthma have yielded inconsistent results $[10,11]$. Only few studies have investigated environmental exposures as risk factors for childhood asthma in south India [1214]. The identification of modifiable risk factors is essential for devising appropriate preventive strategies 
and parental education and hence this study was planned.

\section{Aim}

To study the association between environmental triggers and asthma in children aged 2-15 years attending the pediatric outpatient department of a tertiary care hospital in Erode district, Tamilnadu.

\section{Methodology}

This was a hospital-based Cross-sectional study done at Perundurai Medical college hospital, Erode district, Tamilnadu. The Pediatric department runs a chest clinic and functions as a Referral Centre for asthma. Children from farm-based villages, semi-urban townships and industrial zones with different indoor and outdoor environmental settings attend our paediatric outpatient department and this study was done to gain insights regarding the association of various environmental triggers with childhood asthma. After getting Institutional Ethical Committee approval, the study was done over a period of 4 months from June 2016 to September 2016. Children in the age group of 2 to 15 years attending pediatric OPD were enrolled in the study. Children with systemic illnesses like congestive cardiac failure, chronic renal failure, chronic lung diseases like bronchiectasis, severe anemia, children with severe neurological impairment such as spastic quadriplegic cerebral palsy and immuno-compromised children were excluded. A questionnaire was prepared with excerpts from ISAAC questionnaire for identifying children with asthma [15]. Written consent was obtained from the parents and assent taken from children more than 7 years of age. Students trained in local dialect collected data on basic demographic details, anthropometry, family history, socioeconomic status, exposure to various indoor and outdoor triggers, symptoms related to asthma and treatment details by interviewing the parents.

Medical records were verified to ascertain the diagnosis of asthma. Categorization on nutritional status was done using WHO 2006 MGRS charts for children less than 5 years [16] and revised IAP growth charts for children more than 5 years [17]. Socioeconomic status was classified according to modified Kuppusamy scale [18].

Statistical analysis- Prevalence of demographic characteristics and environmental risk factors among asthmatics and non-asthmatics were calculated using proportions. To test the differences between proportions, Chi- square tests of significance were carried out. Logistic regression analysis (Uni-variate and multi-variate) was applied for identifying the independent risk factors. Statistical analysis was done using SPSS version 16.0 and p-value $<0.05$ was considered statistically significant.

\section{Results}

Out of 510 children enrolled in the study, 8 subjects were excluded based on diagnosis of congestive cardiac failure

Table No.1: Background Characteristics of study participants.

\begin{tabular}{|c|c|}
\hline Background Characteristics & No. (\%) \\
\hline Age in years & $217(43.4)$ \\
\hline $2-5$ & $171(34.2)$ \\
\hline $6-10$ & $112(22.4)$ \\
\hline $11-15$ & $299(59.8)$ \\
\hline Sex & $201(40.2)$ \\
\hline Male & $35(7.0)$ \\
\hline Female & $107(21.4)$ \\
\hline Socio economic status & $358(71.6)$ \\
\hline Upper class & $276(55.2)$ \\
\hline Middle class & $199(39.8)$ \\
\hline Lower class & $25(5 \%)$ \\
\hline Nutritional status & \\
\hline Normal & \\
\hline Under nutrition & \\
\hline Overweight/obese & \\
\hline
\end{tabular}


$(n=2)$, thalassemia $(n=2)$, spastic CP $(n=1)$, acquired immunodeficiency $(n=2)$ and bronchiectasis $(n=1)$. Parents did not give consent for two children $(\mathrm{n}=2)$ and thus 500 participants $(40.2 \%$ girls $)$ were included in the study. Among the study population, 298 children (59.6\%) were asthmatics and 202 children (40.4\%) were non-asthmatics. The majority (43.4\%) of the children belonged to pre-school group 2-5 years and more than two-thirds $(71.6 \%)$ of the children in the study group belonged to lower socioeconomic status. Table 1 shows the background characteristics of the study population.

Table 2 illustrates the association of background variables with asthma. Children aged 6-10 years (OR 1.69, 95\% CI, 1.12-2.56) were at a significantly higher risk for asthma compared to 2-5 year olds, but similar association was not seen with 11-15 years age group. Male gender, history of asthma among first degree relatives, middle and lower socioeconomic status were also significantly associated with childhood asthma. The association of asthma with increased BMI (OR 2.94, 95\% CI, 1.07- 8.07) was statistically significant in comparison with children with normal nutritional status.

Table-2: Association of Background factors with asthma.

\begin{tabular}{|c|c|c|c|c|}
\hline \multirow[t]{2}{*}{$\begin{array}{c}\text { Background } \\
\text { Characteristics }\end{array}$} & $\begin{array}{c}\text { Prevalence among } \\
\text { asthmatics }\end{array}$ & $\begin{array}{c}\text { Prevalence among } \\
\text { non-asthmatics }\end{array}$ & \multirow[t]{2}{*}{$\begin{array}{c}\text { Odds Ratio } \\
\text { (95\% CI) }\end{array}$} & \multirow[t]{2}{*}{ p-value } \\
\hline & No. $(\%)$ & No. $(\%)$ & & \\
\hline \multicolumn{5}{|l|}{ Age in years } \\
\hline $2-5$ & $116(53.5)$ & $101(46.5)$ & 1 & \\
\hline $6-10$ & $113(66.1)$ & $58(33.9)$ & $1.69(1.12-2.56)$ & $0.01 *$ \\
\hline $11-15$ & $69(61.6)$ & $43(38.4)$ & $1.39(0.87-2.22)$ & 0.16 \\
\hline \multicolumn{5}{|l|}{ Sex } \\
\hline Female & $104(51.7)$ & $97(48.3)$ & 1 & \\
\hline Male & $194(64.9)$ & $105(35.1)$ & $1.72(1.19-2.48)$ & $0.003 *$ \\
\hline \multicolumn{5}{|l|}{$\begin{array}{c}\text { Socio economic } \\
\text { status }\end{array}$} \\
\hline Upper class & $14(40.0)$ & $21(60.0)$ & 1 & \\
\hline Middle class & $69(64.5)$ & $38(35.5)$ & $2.72(1.24-5.96)$ & $0.01 *$ \\
\hline Lower class & $215(60.1)$ & $143(39.9)$ & $2.25(1.11-4.58)$ & $0.02 *$ \\
\hline \multicolumn{5}{|l|}{ Nutritional status } \\
\hline Normal & $159(57.6)$ & $117(42.4)$ & 1 & \\
\hline Underweight & $119(59.8)$ & $80(40.2)$ & $1.09(0.75-1.58)$ & 0.22 \\
\hline Over weight/obese & $20(80.0)$ & $5(20.0)$ & $2.94(1.07-8.07)$ & $0.03 *$ \\
\hline \multicolumn{5}{|l|}{$\begin{array}{r}\text { Maternal } \\
\text { Education }\end{array}$} \\
\hline Higher education & $54(57.4)$ & $40(42.6)$ & 1 & \\
\hline Up to High school & $204(58.6)$ & $144(41.4)$ & $1.04(0.66-1.66)$ & 0.83 \\
\hline Illiterate & $40(69.0)$ & $18(31.0)$ & $1.64(0.83-3.28)$ & 0.15 \\
\hline Family h/o Asthma & $81(70.4)$ & $34(29.6)$ & $1.84(1.17-2.88)$ & $0.007 *$ \\
\hline
\end{tabular}

Among various indoor triggers, presence of wall dampness or mould (OR 2.07, 95\% CI, 1.25-3.44) was significantly associated with childhood asthma (Table 3). Children exposed to cockroach and mice antigens, those living in houses with asbestos or thatched roof and usage of LPG as domestic fuel were at increased risk of developing asthma, but the association was not statistically significant. Passive smoking, absence of kitchen smoke outlet at home and stuffed toys were not associated with asthma in our study. 
Original Research Article

Table-3: Association of indoor triggers with paediatric asthma.

\begin{tabular}{|c|c|c|c|c|}
\hline $\begin{array}{c}\text { Environmental risk factors } \\
\text { (Indoor triggers) }\end{array}$ & $\begin{array}{c}\text { Prevalence among } \\
\text { asthmatics } \\
\text { No.(\%) }\end{array}$ & $\begin{array}{c}\text { Prevalence } \\
\text { among non- } \\
\text { asthmatics } \\
\text { No. }(\%)\end{array}$ & $\begin{array}{c}\text { Odds Ratio } \\
(95 \% \mathrm{CI})\end{array}$ & p-value \\
\hline LPG as fuel for cooking & $286(60.5)$ & $187(39.5)$ & $1.91(0.87-4.17)$ & 0.09 \\
\hline Absence of Kitchen chimney/exhaust fan & $264(59.7)$ & $178(40.3)$ & $0.95(0.54-1.66)$ & 0.87 \\
\hline Rat or Mice infestation & $132(61.4)$ & $83(38.6)$ & $1.14(0.79-1.63)$ & 0.48 \\
\hline Presence of cockroaches in houses & $130(62.8)$ & $77(37.2)$ & $1.26(0.87-1.80)$ & 0.22 \\
\hline Passive smoking & $81(58.7)$ & $57(41.3)$ & $0.95(0.64-1.41)$ & 0.79 \\
\hline $\begin{array}{l}\text { Paint/floor refurnishing activities in } \\
\text { home }\end{array}$ & $68(59.6)$ & $46(40.4)$ & $1.00(0.65-1.53)$ & 0.99 \\
\hline $\begin{array}{l}\text { Wall dampness or presence of mould in } \\
\text { wall }\end{array}$ & $65(73.0)$ & $25(27)$ & $2.07(1.25-3.44)$ & $0.004 *$ \\
\hline Stuffed or furry toys & $51(53.7)$ & $44(46.3)$ & $0.74(0.47-1.16)$ & 0.19 \\
\hline $\begin{array}{c}\text { Other irritants - room } \\
\text { perfumes/Cleaning agents }\end{array}$ & $41(61.2)$ & $26(38.8)$ & $1.08(0.63-1.83)$ & 0.77 \\
\hline Electronic appliances i.e. air conditioners & $14(53.8)$ & $12(46.2)$ & $0.78(0.35-1.72)$ & 0.54 \\
\hline \multicolumn{5}{|l|}{ Roof of the House } \\
\hline - Tiles/Concrete & $218(57.4)$ & $162(42.6)$ & 1 & \\
\hline - Asbestos & $28(71.8)$ & $11(28.2)$ & $1.89(0.91-3.91)$ & 0.08 \\
\hline - Thatched & $52(64.2)$ & $29(35.8)$ & $1.33(0.81-2.19)$ & 0.25 \\
\hline
\end{tabular}

Among outdoor triggers, seasonal variation (OR 2.99, 95\% CI, 2.02-4.44) and outdoor air pollution (OR 5.41, 95\% CI, 3.63-8.06) were significantly associated with increased risk of asthma (Table 4). Also, children living in houses in proximity to an arterial road with heavy vehicular traffic, houses surrounded by vegetation and flowering plants and children exposed to building construction dust showed marginally increased risk of asthma, but the association was not statistically significant. The presence of livestock and pet animals was not associated with childhood asthma in our study.

Table-4: Association of outdoor triggers with paediatric asthma.

\begin{tabular}{|c|c|c|c|c|}
\hline $\begin{array}{c}\text { Environmental risk factors } \\
\text { (Outdoor triggers) }\end{array}$ & $\begin{array}{c}\text { Prevalence among } \\
\text { asthmatics } \\
\text { No. (\%) }\end{array}$ & $\begin{array}{c}\text { Prevalence among } \\
\text { non-asthmatics } \\
\text { No. }(\%)\end{array}$ & $\begin{array}{c}\text { Odds Ratio } \\
\text { (95\% CI) }\end{array}$ & p-value \\
\hline Seasonal variation & $236(67.6)$ & $113(32.4)$ & $2.99(2.02-4.44)$ & $<0.001^{*}$ \\
\hline Outdoor air pollution & $189(79.4)$ & $45(19.1)$ & $5.41(3.63-8.06)$ & $<0.001^{*}$ \\
\hline $\begin{array}{c}\text { Proximity to heavy } \\
\text { vehicular traffic }\end{array}$ & $143(61.4)$ & $90(38.6)$ & $1.15(0.80-1.64)$ & 0.45 \\
\hline $\begin{array}{c}\text { Vegetation/flowering plants } \\
\text { around house }\end{array}$ & $82(64.1)$ & $46(35.9)$ & $1.28(0.85-1.95)$ & 0.23 \\
\hline $\begin{array}{c}\text { Livestock / pet animals } \\
\text { Construction activities near } \\
\text { home/school }\end{array}$ & $71(65.7)$ & $46(41.4)$ & $0.95(0.61-1.45)$ & 0.80 \\
\hline
\end{tabular}

Multivariate logistic regression analysis revealed age group 6-10 years (as compared to 2-5 years), male gender, overweight/obesity, middle and lower socioeconomic status, presence of mould, seasonal variation and outdoor air pollution as independent risk factors for childhood asthma (Table 5). 
Table No.-5: Association of various factors with childhood asthma- Logistic Regression.

\begin{tabular}{|c|c|c|c|c|}
\hline $\begin{array}{c}\text { Background } \\
\text { characteristics }\end{array}$ & Unadjusted OR & $\begin{array}{l}\text { Adjusted } \\
\text { OR }\end{array}$ & 95\% CI for Adjusted OR & p-value \\
\hline \multicolumn{5}{|l|}{ Age in years } \\
\hline $2-5$ & 1 & 1 & & \\
\hline $6-10$ & 1.69 & 1.94 & $1.20-3.13$ & $0.006^{*}$ \\
\hline $11-15$ & 1.39 & 1.45 & $0.84-2.52$ & 0.18 \\
\hline \multicolumn{5}{|l|}{ Sex } \\
\hline Female & 1 & 1 & & \\
\hline Male & 1.72 & 2.26 & $1.47-3.48$ & $<0.001^{*}$ \\
\hline \multicolumn{5}{|l|}{ Socio economic status } \\
\hline Upper class & 1 & 1 & & \\
\hline Middle class & 2.72 & 2.85 & $1.25-6.48$ & $0.01 *$ \\
\hline Lower class & 2.25 & 3.82 & $1.55-9.36$ & $0.003^{*}$ \\
\hline \multicolumn{5}{|l|}{ Nutritional status } \\
\hline Normal weight & 1 & 1 & & \\
\hline Underweight & 1.09 & 1.03 & $0.67-1.59$ & 0.87 \\
\hline Over weight/obese & 2.94 & 3.70 & $1.17-11.66$ & $0.03 *$ \\
\hline Family H/o Asthma & 1.84 & 1.55 & $0.93-2.59$ & 0.09 \\
\hline \multicolumn{5}{|l|}{ INDOOR TRIGGERS } \\
\hline Wall dampness/ mould & 2.06 & 2.43 & $1.37-4.32$ & $0.002 *$ \\
\hline \multicolumn{5}{|l|}{ Roof of the House } \\
\hline -Tiles/Concrete & 1 & 1 & & \\
\hline -asbestos & 1.89 & 2.20 & $0.95-5.09$ & 0.06 \\
\hline -thatched & 1.33 & 1.54 & $0.87-2.73$ & 0.13 \\
\hline \multicolumn{5}{|l|}{ OUTDOOR TRIGGERS } \\
\hline Outdoor air pollution & 5.41 & 6.17 & $4.00-9.53$ & $<0.001 *$ \\
\hline Seasonal variation & 2.99 & 2.39 & $1.51-3.79$ & $<0.001 *$ \\
\hline
\end{tabular}

\section{Discussion}

Among the etiological factors of asthma, the role of environmental determinants has been entangled between "hygiene hypothesis" and "immuno-tolerance hypothesis" [19]. Some triggers like pet danders exhibit a complex relationship, with early childhood exposure offering protective effect and late childhood exposure precipitating asthma [20].

In our study, age group of 6-10 years was found to be independently associated with asthma as compared to the preschool age group. Another South Indian study has reported such independent association of 6-9 years age group with bronchial asthma among school going children [21]. Male gender was also found to be an independent risk factor for childhood asthma, in similar with other studies $[13,22]$. This male predominance is due to the relatively narrow airways of boys which persist till adolescence. Children belonging to middle and lower socio-economic classes had significantly increased risk of asthma. This may be attributed to chronic stress, endotoxin exposure, inadequate ventilation of living places and poor compliance with preventive medications associated with low-income households. A longitudinal study in Australia has observed a protective effect against asthma among children whose families had moved out of poverty [23].

By acting as a mechanical inhibitor to the development of normal lung function and augmentation of inflammatory cytokines, obesity and overweight have been postulated as a contributor of observed worldwide asthma epidemic [19]. A meta-analysis of prospective studies has reported a $50 \%$ increase in incidence of asthma among overweight/obese adults [24]. In our 
study, overweight and obese children were at 3.7 times higher risk of developing asthma and increased BMI was an independent predictor of childhood asthma. Family history of asthma was not an independent predictor of childhood asthma in our study which was in contrast to a recent Indian study [21]. Inclusion of preschool age group in our study could have resulted in this difference.

Among the environmental risk factors, presence of wall dampness or mould was an independent risk factor for asthma. The association of moisture damage and mould growth in the main living quarters with the development of asthma in early childhood has been documented in a Finnish population-based case-control study [25]. In our study, seasonal variation was an independent risk factor for childhood asthma similar to a recent study from Korea [26]. Seasonal variation of symptoms in asthmatic children can be attributed to bronchospasm induced by respiratory viral epidemics, declining mean temperature, cold dry air, airborne allergens like pollens and smog acting as triggers.

Outdoor air pollution (exposure to high atmospheric particulate matter levels and toxic gases) was independently associated with increased risk of asthma in children. Guarnieri and Balmes [27], in their review series have elaborated the role of outdoor air pollutants in the exaggeration of pre-existing asthma and also in the induction of new onset asthma in children and adults. There was no significant risk of asthma in children whose houses were situated within 500 feet $(150 \mathrm{~m})$ of road with heavy vehicular traffic, which was in contrary to a south Californian cohort study [28]. This could be due to the reporting bias of the parents in our study regarding the exact distance of the house from the arterial road.

In our study, passive smoking was not associated with increased risk of asthma similar to a study from rural Puducherry [14]. This is in concurrence with a systematic review which postulated that environmental tobacco smoke (ETS) can be considered as a co-factor provoking wheezing attacks, rather than a cause of the underlying asthmatic tendency [29].

Type of fuel used for cooking and absence of kitchen chimneys were also not significantly associated with childhood asthma in our study. Kumar et al [30] have reported a lower prevalence of asthma in children with smoke outlets in their houses, though there was no association with the type of fuel used. We could not find any significant association regarding exposure to mice, cockroach, livestock and pet animals with risk of childhood asthma, which was similar to several studies [22,31]. In contrary, a study from Beijing have reported increased risk of asthma for those having both a dog and a cat as pets or for finding both cockroaches and rats inside their houses [32].

We acknowledge certain limitations of our study. Our study was based on history of exposure to indoor and outdoor triggers and not on allergen-specific serum IgE or skin prick tests. Biomarkers do not always correlate well with clinical disease [19] and are also expensive. Being a questionnaire based study, the results may be influenced by the memory bias or reporting bias of the parents regarding the presence or absence of environmental risk factors.

\section{Conclusion}

Environmental determinants play a significant role in inducing childhood asthma. In developing countries, identification of specific risk factors for the particular child is a challenging task for the treating physician. General non-pharmacological measures like reduction in exposure to outdoor air pollution, protective care during seasonal changes and creating child-friendly homes with prevention of mould formation may help in decreasing the asthma related morbidity. Efforts to check the rise in childhood overweight and obesity are necessary to prevent asthma and other associated complications.

\section{Abbreviations}

ISAAC- The International Study of Asthma and Allergies in Childhood

MGRS- Multicenter Growth Reference Study

BMI- Body Mass Index

LPG- Liquefied Petroleum Gas

Funding: Nil, Conflict of interest: None initiated, Perission from IRB: Yes

\section{References}

1. Strachan DP. The epidemiology of childhood asthma. Allergy 1999 Mar; 54 (49):7-11.doi:10.1111/j. 13989995. 1999.tb04381.x.

2. Reddel HK, Bateman ED, Becker A, Boulet LP, Cruz AA, Drazen JM, Haahtela T, Hurd SS, Inoue H, de Jongste JC, Lemanske RF Jr, Levy ML, O'Byrne PM, Paggiaro P, Pedersen SE, Pizzichini E, Soto-Quiroz M, 
Szefler SJ, Wong GW, FitzGerald JM. A summary of the new GINA strategy: a roadmap to asthma control. Eur Respir J. 2015 Sep; 46(3):622-39. doi: 10.1183/ 13993003. 00853-2015. Epub 2015 Jul 23.

3. Marks G, Pearce N, Strachan D, Asher I. Global burden of disease due to asthma. In: The Global Asthma Report 2014. Auckland, New Zealand: Global Asthma Network, 2014. p. 16-21.

4. Eder W, Ege MJ, von Mutius E. The asthma epidemic. N Engl J Med. 2006 Nov 23;355(21): 2226-35.

5. Asher MI, Montefort S, Björkstén B, Lai CK, Strachan DP, Weiland SK, Williams H; ISAAC Phase Three Study Group. Worldwide time trends in the prevalence of symptoms of asthma, allergic rhinoconjunctivitis, and eczema in childhood: ISAAC Phases One and Three repeat multicountry crosssectional surveys. Lancet. 2006 Aug 26;368(9537): 733-43.

6. Worldwide variation in prevalence of symptoms of asthma, allergic rhinoconjunctivitis, and atopic eczema: ISAAC. The International Study of Asthma and Allergies in Childhood (ISAAC) Steering Committee. Lancet. 1998 Apr 25;351(9111):1225-32.

7. Subbarao P, Mandhane PJ, Sears MR. Asthma: epidemiology, etiology and risk factors. CMAJ. 2009 Oct 27; 181(9):E181-90. doi: 10.1503/cmaj. 080612. Epub 2009 Sep 14.

8. Wang HY, Wong GW, Chen YZ, Ferguson AC, Greene JM, Ma Y, Zhong NS, Lai CK, Sears MR. Prevalence of asthma among Chinese adolescents living in Canada and in China. CMAJ. 2008 Nov 18;179 (11):1133-42. doi: 10.1503/cmaj.071797.

9. Liu AH, Covar RA, Spahn JD, Sicherer SH. Childhood asthma. In: Kliegman RM, Stanton BF, St Geme JW, Schor NF, editors. Nelson textbook of pediatrics. New Delhi (India): Reed Elsevier India; 2016. p. 1097.

10. Strachan DP. The role of environmental factors in asthma. Br Med Bull. 2000;56(4):865-82.

11. Gowers AM, Cullinan P, Ayres JG, Anderson HR, Strachan DP, Holgate ST, et al. Does outdoor air pollution induce new cases of asthma? Biological plausibility and evidence; a review. Respirology 2012 Aug;17 (6): 887-98. doi: 10.1111/j.1440-1843. 2012. 02195.x.

12. Chakravarthy $\mathrm{S}$, Singh RB, Swaminathan $\mathrm{S}$, Venkatesan P. Prevalence of asthma in urban and rural children in Tamil Nadu. Natl Med J India. 2002 SepOct; 15(5):260-3.

13. Dhabadi BB, Athavale A, Meundi A, Rekha R, Suruliraman M, Shreeranga A, Gururaj S. Prevalence of asthma and associated factors among schoolchildren in rural South India. Int J Tuberc Lung Dis. 2012 Jan;16 (1):120-5. doi: 10.5588/ijtld.11.0195

14. Kumar SG, Premarajan KC, Sarkar S, Sahu SK, Sahana, Ambika, et al. Prevalence and factors associated with asthma among school children in rural Puducherry, India. Curr Pediatr Res 2012;16(2):159-63.

15. Asher MI, Keil U, Anderson HR, Beasley R, Crane J, Martinez F, Mitchell EA, Pearce N, Sibbald B, Stewart AW, et al. International Study of Asthma and Allergies in Childhood (ISAAC): rationale and methods. Eur Respir J. 1995 Mar;8(3):483-91.

16. WHO Multicentre Growth Reference Study Group. WHO Child Growth Standards: Length/height-for-age, weight-for-length, weight-for-height and body mass index-for-age: Methods and development. Geneva: World Health Organization, 2006 (312 pages).

17. Khadilkar VV, Khadilkar AV. Revised Indian Academy of Pediatrics 2015 growth charts for height, weight and body mass index for 5-18-year-old Indian children. Indian J Endocrinol Metab. 2015 Jul-Aug;19 (4): 470-6. doi: 10.4103/2230-8210.159028.

18. Oberoi SS. Updating income ranges for Kuppuswamy's socio-economic status scale for the year 2014. Indian J Public Health. 2015 Apr-Jun;59(2):1567. doi: 10.4103/0019-557X.157540.

19. Johnson CC, Ownby DR, Zoratti EM, Alford SH, Williams LK, Joseph CL. Environmental epidemiology of pediatric asthma and allergy. Epidemiol Rev. 2002; 24 (2):154-75

20. Apelberg BJ, Aoki Y, Jaakkola JJ. Systematic review: Exposure to pets and risk of asthma and asthma-like symptoms. J Allergy Clin Immunol. 2001 Mar;107(3):455-60. 
21. Jain A, Vinod Bhat H, Acharya D. Prevalence of bronchial asthma in rural Indian children: a cross sectional study from South India. Indian J Pediatr. 2010 Jan;77(1):31-5. doi: 10.1007/s12098-009-0308-6. Epub 2010 Jan 20.

22. George CE, Chopra H, Garg SK, Bano T, Jain S, Kumar A. Environmental correlates of bronchial asthma in children in a slum of Meerut - A cross-sectional study. Int J Med Res Rev 2014 Sep-Oct;2(5):469-473. doi: 10.17511/ijmrr.2014.i05.012.

23. Kozyrskyj AL, Kendall GE, Jacoby P, Sly PD, Zubrick SR. Association between socioeconomic status and the development of asthma: analyses of income trajectories. Am J Public Health. 2010 Mar;100(3):5406. doi: 10.2105/AJPH.2008.150771. Epub 2009 Aug 20.

24. Beuther DA, Sutherland ER. Overweight, obesity, and incident asthma: a meta-analysis of prospective epidemiologic studies. Am J Respir Crit Care Med. 2007 Apr 1;175(7):661-6. Epub 2007 Jan 18.

25. Pekkanen J, Hyvärinen A, Haverinen-Shaughnessy U, Korppi M, Putus T, Nevalainen A. Moisture damage and childhood asthma: a population-based incident case-control study. Eur Respir J. 2007 Mar;29(3):50915. Epub 2006 Nov 15.

26. Won YK, Hwang TH, Roh EJ, Chung EH. Seasonal patterns of asthma in children and adolescents presenting at emergency departments in Korea. Allergy
Asthma Immunol Res 2016 May; 8 (3): 223-9. doi: 10. 4168 /aair.2016.8.3.223.

27. Guarnieri M, Balmes JR. Outdoor air pollution and asthma. Lancet. 2014 May 3;383(9928):1581-92. doi: 10. 1016/S0140-6736(14)60617-6.

28. McConnell $\mathrm{R}$, Berhane $\mathrm{K}$, Yao L, Jerrett $\mathrm{M}$, Lurmann F, Gilliland F, Künzli N, Gauderman J, Avol E, Thomas D, Peters J. Traffic, susceptibility, and childhood asthma. Environ Health Perspect. 2006 May; 114 (5):766-72.

29. Strachan DP, Cook DG. Health effects of passive smoking. 6. Parental smoking and childhood asthma: longitudinal and case-control studies. Thorax.1998 Mar; 53 (3):204-12.

30. Kumar GS, Roy G, Subitha L, Sahu SK. Prevalence of bronchial asthma and its associated factors among school children in urban Puducherry, India. J Nat Sci Biol Med. 2014 Jan;5(1):59-62. doi: 10.4103/09769668. 127289.

31. Singh D, Sobti PC, Arora V, Soni RK. Epidemiological study of asthma in rural children. Indian J Community Med 2002 Oct-Dec;27(4):167-70.

32. Zheng T, Niu S, Lu B, Fan X, Sun F, Wang J, Zhang Y, Zhang B, Owens P, Hao L, Li Y, Leaderer B. Childhood asthma in Beijing, China: a population-based case-control study. Am J Epidemiol. 2002 Nov 15;156 (10):977-83.

\section{How to cite this article?}

Muraleetharan G, Anuradha G, Vanishree S, Sachithanantham S. Environmental risk factors for childhood asthma in a Semi-urban area of Western Tamilnadu. J PediatrRes.2017;4(03):211-218.doi:10.17511/ijpr.2017.i03.03. 